http://journals.ums.ac.id/index.php/ijolae

\title{
Inclination of Students towards Active Participation in Extracurricular Activities as an Effective Tool for Professional Development during Education in Pakistan
}

\author{
Abdul Rahman', Rabia Ali Hundal ${ }^{2}$ \\ ${ }^{1}$ Department of Materials Science \& Engineering, Institute of Space Technology, Pakistan \\ ${ }^{2}$ Department of Space Science, Institute of Space Technology, Pakistan
}

DOI: 10.23917/ijolae.v3i2.12026

Received: September $1^{\text {st }}, 2020$. Revised: December 21 $1^{\text {st }}, 2020$. Accepted: December $27^{\text {th }}, 2020$. Available Online: January $11^{\text {st }}, 2021$. Published Regularly: May $1^{\text {st }}, 2021$.

\begin{abstract}
Extracurricular activities (ECA) are, nowadays, considered as an essential part of any school system of any level. The present study reveals the relation of ECA with student's performance, academic achievements, career selection and, last but not the least, professional development (PD) of students in Pakistan. The research was carried out by developing a questionnaire. It consists of five comprehensive questions relating the ECA with PD. The validity and reliability of questions were checked. The research population consisted of students, with some managerial and leadership experience, from different institutes of Pakistan. The sample consist of majorly all the members of the respective population. After purposively selection, the questionnaire was distributed among 110 selected members of populations for research. Response rate was $90.9 \%$ as 100 members filled the form and all the responses was considered valid for the statistical study. Different statistical methods were used to carry out the research consisting of standard deviation, arithmetic means etc. It was clearly observed the respondent's consideration of ECA as tool for PD of students is high. It was also observed that consideration of ECA for cultivation of interpersonal skills is high and same rate was high for ECA's impact on career selection. In addition to this, the consideration rate of ECA for improving of managerial skills and self-efficacy is high. So, it is concluded that educational institutes should motivate their students to participate in ECA for better a career.
\end{abstract}

Keywords: career development, extracurricular activities, interpersonal skills, professional exellence education, professional development

\section{Corresponding Author:}

Abdul Rahman, Department of Materials Science \& Engineering, Institute of Space Technology, Pakistan

Email: rahman.abdul1453@gmail.com

\section{Introduction}

Success story of an educational institution does not depend entirely on the quantity of students but more on the quality of students that are graduating. Alumni is an important source of recognition of their institutes in industries or respective work fields. The professional development of students for practical life entirely depends upon the environment provided by their educational institutes.

Students, during their studies, do face many problems which can negatively or in some cases positively affects their produc- tivity and competency (Ji \& Zhang, 2011). A student faces various stresses which may be because of workload or of emotions. Identification of such problems and addressing them timely will enable them to give their best for their prosperous future as by limiting the students to study only may result in psychological stress and anxiety among them. Sometimes, counselling is not the only approach to address those problems for better career and professional development (PD) of a student.

Nowadays, most of the organizations seek a person who excels in both science and 
arts. For a person to be polymath (Dalrymple \& Evangelou, 2006), it is important to have diverse professional experience that is only possible via communicating and interacting with society. Interaction can result in raising of confidence or it might cause depression to someone depending upon the scenario. Professional development of a person for his/her career is crucial as working environment of any organization is competitive. For someone to make his/her place in their respective organization, it is important to have multiple skills on hand.

Rubin et. al summarizes that a wellrounded candidate is more appealing for an organization. A student with wide experience and exposure, is emotionally stable (van Loon et al., 2020) and strong, intelligent and expected to be efficient too. The nature of activity in which the student is participating is not important as the nature of students' experience in that particular activity is considerable. Basically, ECA is one of many categorization tools for identifying the skills, attitude and amplitude of student for a particular professional working environment. (Staff, Messersmith, \& Schulenberg, 2009).

Extracurricular Activities (ECA) plays an important role in reducing stresses or anxieties (van Loon et al., 2020). A polymath student actively participates in ECA for enhanced skills set. Many institutes have encouraged and appreciated students for active participation in ECA as this experience is considered as an important part for PD of any student (Ji \& Zhang, 2011).

The researchers of current study strongly believe that a student having an active participation in ECA with a good academic background is capable of responding to most of the problems, effectively while working in any professional firm or organization. Such a student is competent enough to complete task(s) with perfection and confidence. The same person is capable to marketing the organization before many stakeholders for better collaboration (Jackson \& Bridgstock, 2020).

ECA provide students with many opportunities. ECA benefits the students by improving his/her response to competitive environments. ECA extemporizes leadership and teamwork in them along with other skills (Perjuangan, 2020), ECA also reduces drug addiction and other related problems. These activities induce better rate of self-esteem and a concept of being at the top by giving the best. In order to have good standings, a student must keep a balance between academics and ECA.

According to Massoni et. al, ECA plays an important role for polishing the skill set of students. ECA improves student's behaviour to work in a professional environment. The students try to find something while participating in ECA that will help them in their career. These activities have a positive impact on students' attitude, attire, performance and ultimately in making them a successful adult (Massoni, 2011).

Keeping in view the abovementioned aspects of ECA, it is the time to identify the role of ECA for better career and PD of student. ECA affects one behaviour and character in both positive and negative ways. The importance and need of present study are the identify the need of ECA for students in an institution and how these activities are fruitful for an individual in their professional life and for the society as well.

Professional development (PD) is a term with a wide spectrum of domains. PD is a way of achieving the academic degrees and the credentials linked with professional earning. This learning method constitutes of a numerous path for achieving the goals by attending workshops or conferences, completing the formal coursework or may be by taking advantage from the informal learning 
opportunities through various platform. PD is a collaborative approach for better results by the employees of any organization and the opportunities linked with that organization. Mentoring, technical support, consultation, counselling, guidance and supervision and learning lessons are some of many ways of approaching PD (Kirsch, Aleksić, Mortini, \& Andersen, 2020).

Holloway et. al links the PD to gains in student learning. He concludes his study with an argument that student achievement and the overall effectiveness of a school can be improved by more effective and research-based PD methods. The active involvement of instructors and leaders of a certain school directly enhance the student learning, productivity and their efficacy as well (Holloway, 2006).

Extracurricular Activities (ECA) are considered to be well-integrated part of education in any school. These activities include, but not limited to, performing arts, contests and competitions, athletics, debating, literary contests, blogging, student societies, student clubs and councils along with numerous social events. Well, these activities add no credit to graduation in terms of academics but due to involvement of these activities, a student develops a multitude of work experience in his/her personality (Abizada, Gurbanova, Iskandarova, \& Nadirzada, 2020). These activities are mostly voluntary and supported and supervised by officials of that school or any leader. The impact of these activities on student's academic achievements provides a room for debate. Participation in ECA is stemmed from the intrinsic interest of a student. ECA develop sense of competitive spirit among students. ECA makes students fit to achieve their future goals. Co-operation, leadership skills, social interaction, self-confidence, punctuality and team-working spirit are some other major attributes provided by ECA
(Dhanmeher, 2014; Oberle, Ji, Guhn, Schonert-Reichl, \& Gadermann, 2019).

Lunenburg et. al moderates that ECA serves same as elective courses serves in academics. The experience acquired by these are not included in the formal course work and they help students to apply the acquired knowledge through formal studies for better democratic life. By working in clubs, the learning is reinforced as well. ECA supplements the elective course work and being involved in leisure-time activities, it enriches the overall learning experience of a student (Guilmette, Mulvihill, Villemaire-Krajden, \& Barker, 2019). ECA ties up many aspects of experience and knowledge hence integrating the knowledge as it is considered to be the most important objective of overall learning process. And last but not the least by participating in the administrative tasks of student societies and clubs, a student learns the way of handling administrative issues, planning, organizing and managing many different aspects which are very beneficial for his/her democratic life (Green, 1987).

A relation between academic and activities like ECA has been studied by Huang et. al. The study shows a positive and linear growth in the affective as well as cognitive growth of student. The schools that encourages their students to participate in ECA though means of student affairs department by initiating clubs, societies and student leadership platforms, produces most well-rounded and productive students for industries (Huang \& Chang, 2004).

For a student to work effectively in an organization, his/her professional development (PD) is very important. PD is not limited to good grade point average (GPA) but ECA plays a vital role in it. Educational organizations are responsible for producing such graduates which are well professionally developed to meet expectations of any organization. 
ECA, being a source of enhancing communication skills and confidence, affects the working performance of students in a very positive and progressive way (Fitriansyah, R., Fatinah, L., \& Syahril, M. (2020: 109-119).

It is suggested by many researchers to participate in ECA as it has positive impact on one's behaviour. The reason behind it is the observation of one's response towards problem solving and project managing. The following questions addresses the problem of this study: (a) extracurricular activities are one of the many tools for professional development of students; (b) extracurricular activities assists a student for the cultivation of interpersonal skills; (c) extracurricular activities helps a student for selection of career based on one's interests, competency and capability; (d) extracurricular activities guides a student regarding time, project, risk, resources and financial management for professional life; and (e) extracurricular activities has a significant impact on domestic and social work of a student for skill set development and improvement for democratic life.

The main objective of present research is the study of (a) importance of ECA for students; (b) importance of ECA for PD of students; and (c) impact of ECA on personal and professional skills development of students.

The present research on theoretical as well as practical levels. The first is the present research is theoretically significant as it identifies the impact of ECA on personal and professional development of a student for any professional firm or organization and tt will be a vital addition to the literature regarding effect of ECA on students' career and personality.

The second is to present research is practically significant as it will motivate the educational institutions to encourage their students to participate in ECA for better repute among professional firms or organizations by producing well-rounded, well-mannered and productive students that can be easily adjusted to any competitive environment.

\section{Method}

\section{a. The Approach of Research}

The approach for this research was a correlative descriptive one. Data collection was fulfilled by reviewing the relevant literature and a questionnaire. Many researchers do have adopted this approach by offering their readers a little and precise description of items. The acceptance of the adopted attributes can be done by using it (Lawless \& Heymann, 2010).

\section{b. The Population and Sample of Re- search}

The population for this research represents students, studying in different institutes having an interest in participating in ECA and have some leadership background. The population consisted of 110 students consisting of 80 male and 30 female students. The selected purposive sample represented the research's population. The developed questionnaire was distributed among the sample. 100 questionnaires out of 110 was retrieved and were considered to be valid for our statistical analysis. Yet the response rate was $90.9 \%$, which is quite accepted and appreciated for the researchers for continuation of research.

\section{c. The Research's Instrument}

In order to accomplish the research's goals, a five problems-based questionnaire was developed along with the adaptation of five-point Likert scale. The mentioned scale constitutes five different categories of strongly agree, agree, neutral, disagree and strongly disagree. The represented categories follow the scores respectively: 5, 4, 3, 2 and 1. 
The validity of the instrument was measured by checking the validity of content. Several experts and teachers having expertise and knowledge, checked the questionnaire. After reviewing, the recommendation was to keep the questionnaire with some minor changes with respect to available literature.

\section{d. Criteria for Means Classification}

The below-mentioned equation was used in order to set a criterion for classification of means:

$$
\begin{gathered}
\text { Gap between two criteria }=\frac{\text { Maximum Value }- \text { Minumim Value }}{\text { Number of required criteria }} \\
\text { Gap between two criteria }=\frac{5-1}{3}=\mathbf{1 . 3 3}
\end{gathered}
$$

The criteria, as used by Al-tarawneh et. al, were finalized by adding the resultant gap in each value as listed below (Al-tarawneh \& Battah, 2020): (a) low, Greater than or equal to 1.00 - Less than 2.33; (b) moderate, Greater than or equal to 2.33 - Less than 3.66; and (c) high, Greater than or equal to $3.66-$ Less than 5.00.

\section{Result and Discussion}

\section{a. First Question}

Question 1: Extracurricular Activities are one of the many tools for professional development of students can be seen in Table 1 .

Table 1 Statistical Calculations of First Question

\begin{tabular}{cccc}
\hline Gender & Arithmetic Mean & Standard Devition & Degree \\
\hline Male & 4.45 & 0.66 & High \\
Female & 4.67 & 0.47 & High \\
Total & 4.53 & 0.70 & High \\
\hline
\end{tabular}

Based on Table 1, it was observed that consideration of ECA as a tool for PD of student is high as total mean is 4.53 and the standard deviation in 0.70 . It was also observed that consideration of ECA as a significant tool is relatively high in female students than that of male students as mean is 4.67 and 4.45 respectively.

For a young graduate, the transition phase from university to work is critically important. This is the point where many student faces difficulties in finding first job and more likely to face mismatch and other problems like that of underemployment. In job market, the supply of job seekers is more than the demand. it is difficult to select an employee from a pool of candidates. Therefore, emplo- yers place higher criteria of selection. Hence, the student who participates in ECA positively is considered to be a better option for the job as he/she is capable to putting extra effort in order to complete a particular task. The participation in ECA imparts decision making, teamwork in a student, hence improving the professional ethics and practices of how to deal with staff members, coaches, head and adjustment in a new environment in oneself (Nuijten, Poell, \& Alfes, 2017). The researchers of latter study stated that recruiters appreciate students to participate in ECA as it fosters different value-added qualities in them. According to Stephens and Schaben, students who actively participate in ECA have good GPA, low absenteeism and higher edu- 
cational ambitions (Stephens \& Schaben, 2002).

\section{b. Second Question}

Question 2: Extracurricular Activities assists a student for the cultivation of interpersonal skills (see Table 2).

Table 2 Statistical Calculations of Second Question

\begin{tabular}{cccc}
\hline Gender & Arithmetic Mean & Standard Devition & Degree \\
\hline Male & 4.48 & 0.70 & High \\
Female & 4.70 & 0.46 & High \\
Total & 4.56 & 0.64 & High \\
\hline
\end{tabular}

Based on Table 2, it was observed that consideration of ECA for cultivation of interpersonal skills of a student is high as total mean is 4.56 and the standard deviation in 0.64 . It was also observed that consideration rate is relatively high in female students than that of male students as mean is 4.70 and 4.48 respectively.

Interpersonal skills mainly comprise of communication skills like listening, understanding and the way of interaction. By participating in ECA, student meets different people. By interacting with ones from different backgrounds, they share ideas and respects each other's opinion. In this way they learn how to work in groups regardless of gender stereotypes (Massoni, 2011). By organizing workshops or interactive sessions, organizations can provide a platform to adolescents to socialize and share their success stories, abilities and achievements that encourages the fellows or listeners to participate in ECA for fruitful future endeavour (Huang \& Chang, 2004). Rubin et al. concludes ECA as a vital indicator of interpersonal skills as they are directly linked with the abilities of teamwork, decision making and initiating as well as with communication skills (Staff et al., 2009). Student participation in ECA have always shown a positive impact on their personality and success. Participation in extracurricular activities always help students to learn about the valuable qualities linked with the hidden curriculum of ECA. Such activities build the spirits of teamwork, dedication, and positivity among students and their community (Craft, 2012).

\section{c. Third Question}

Question 3: Extracurricular Activities helps a student for selection of career based on one's interests, competency and capability (see Table 3).

Table 3 Statistical Calculations of Third Question

\begin{tabular}{cccc}
\hline Gender & Arithmetic Mean & Standard Devition & Degree \\
\hline Male & 4.39 & 0.74 & High \\
Female & 4.44 & 0.61 & High \\
Total & 4.41 & 0.69 & High \\
\hline
\end{tabular}

Table 3 reflects that consideration of ECA as an assistance for selection of career is high as total mean is 4.41 and the standard deviation in 0.69 . It was also observed that consideration rate is relatively high in female students than that of male students as mean is 4.44 and 4.39 respectively.

By participating in ECA, students expect to expand their social circle, improve their personal skills and development, improve 
their position in society, finding ways of earning money and scavenging employment opportunities (Lindsey van der Lans, 2012). Participation in activities enables students to get the chance of learning group and individual responsibilities, other than building stamina and patience these activities help students to perform well in academics. These activities boost student attachment to the school, and it leads to less risk of failure (BAHDI, 2014). In addition to this, by motivating student to participate in ECA, enables them to explore one's interests, talents and skills and the environment where they can work with dedication by utilizing all their capabilities (Denault,
Ratelle, Duchesne, \& Guay, 2018). ECA always pay a positive effect on the student academics especially when they are linked with a balanced life and self-confidence (Tanner, 2017). By engaging effectively in career development programs during studies results in many fruitful outcomes among them the most important one is satisfaction in job and employment (Staff et al., 2009).

\section{d. Fourth Question}

Question 4: Extracurricular Activities guides a student regarding time, project, risk, resources and financial management for professional life (see Table 4).

Table 4 Statistical Calculations of Forth Question

\begin{tabular}{cccc}
\hline Gender & Arithmetic Mean & Standard Deviation & Degree \\
\hline Male & 4.39 & 0.80 & High \\
Female & 4.57 & 0.66 & High \\
Total & 4.45 & 0.75 & High \\
\hline
\end{tabular}

Based on the calculations in Table 4, is was found that consideration of ECA for helping a student regarding management of different aspects is high as total mean is 4.45 and the standard deviation in 0.75 . It was also observed that consideration rate is relatively high in female students than that of male students as mean is 4.57 and 4.39 respectively.

ECA imparts different hidden qualities like time management, leadership skills, project and risk management, utilization of resources in a useful way, resilience etc. Time management is one of the lifelong lessons by ECA. ECA enable student to keep time balance between school/college, sports, friends and family and other activities in which they are participating. By participating in ECA, one can learn the ways to motivate their team to work efficiently, simply called as leadership. In this way they learn conflict management and ultimately, they found these skills as very useful tool to survive in a professional working environment (Craft, 2012). A student leader who knows how to manage time, risk factor, finances and resources eventually has better project management skills. Project management depends on how someone manages everything for a better result. The one who have managerial background knows the way to complete the project by prioritizing the tasks. Better management of time, tasks, resources, conflicts and finances ultimately completes the project in a very perfect way (King, McQuarrie, \& Brigham, 2020).

\section{e. Fifth Question}

Question 5: Extracurricular Activities has a significant impact on domestic and social work of a student for skill set development and improvement for democratic life (see Table 5). 
Table 5. Statistical Calculations of Fifth Question

\begin{tabular}{cccc}
\hline Gender & Arithmetic Mean & Standard Deviation & Degree \\
\hline Male & 4.39 & 0.67 & High \\
Female & 4.54 & 0.56 & High \\
Total & 4.44 & 0.64 & High \\
\hline
\end{tabular}

Based on Table 5, it was observed that consideration of ECA for improving self-efficacy of a student is high as total mean is 4.44 and the standard deviation in 0.64 . It was also observed that consideration rate is relatively high in female students than that of male students as mean is 4.54 and 4.39 respectively.

ECA allows students to become a part of administrative teams of different student clubs or societies, advisory or mentoring groups or may be of different well-organized activities. ECA fulfils the vital and actual objective of today's democratic life. The living of actual democratic life should not be restricted to the formal setting of a classroom. The sense of cooperation and teamwork is necessary to work in a democratic society (Green, 1987). Saibovich et. al suggested that ECA are an essential source of development of an individual life to survive in democratic society. ECA helps to improve leadership skills, command on communication skills and develop strategic thinking among students (Saibovich, 2019). ECA have always been emphasized by its supporters to enable youth so they can socialize with peers and adults. It helps them to get determined enough to set goals and compete for them, power to recover from defeat and resolve issues amiably (Rees, 2008).

Present study shows high degree of all five mentioned indicators, which is due to the careful selection of audience for study. The scrutiny of audience was done after critical checking of their active participation in ECA. The high degree corresponds to the inclination of audience towards positive results in PD through active participation in ECA.

\section{Conclusion}

After statistical analysis of the data, it is clear that participation in ECA results in positive impact on performance and achievements of a student. Research showed that participation in ECA enables a student to learn notable qualities linked with ECA's hidden curriculum. Participation in ECA adds on to the student personal and professional development in order to build a positive relation with society for their better democratic life. From the results of aforementioned research, it has been concluded that ECA participation helps in attaining the outcomes of academic learning which is a preparation indictor of a student to work in professional environment, hence ultimately contributes to the professional development of a student.

The practical implications is to improve employment chances of a fresh graduate and for better PD of a student, they should be encouraged to participate in ECA. From the results of aforementioned study, it is clear that a student who participates in ECA positively have better time, project, risk, conflict, resources management skills, along with leadership and teamwork skills and good professional ethics. Their connection with school, classroom behaviour and their GPA will also improve. Educational institutions should play their part to motivate students towards active participation in ECA for their prosperous future.

Our study provides a gateway for researchers to study impact on student's personality who actively participates in ECA. PD of faculty in educational institutions and professionals in firms or organizations has been 
focused. The study emphasis on PD of students for their future. The present study has been limited due to selected audience however the room for study is to examine the impact on student's personality and attitude by further classifying ECA into different types like literary, technical, fine as well as performing arts. The study can be further extended by selecting a wide spectrum of audience from different backgrounds.

\section{Acknowledgements}

The authors would like to thank the respondents who participated in this research.

\section{References}

Abizada, A., Gurbanova, U., Iskandarova, A., \& Nadirzada, N. (2020). The Effect of Extracurricular Activities on Academic Performance in Secondary School: The Case of Azerbaijan. International Review of Education, (0123456789). https://doi.org/10.1007/s11159-02009833-2

Al-tarawneh, H., \& Battah, A. (2020). The Relationship Between Psychological Stress and Self-efficacy Among the Educational Supervisors in Karak. Journal of Education and Practice, 11(6), 102112. https://doi.org/10.7176/JEP/11-613

Bahdi, M. (2014). The Impact of Extracurricular Activities on Students' Academic Oral Proficiency. Kasdi Merbah University - Ouargla.

Craft, S. W. (2012). The Impact of Extracurricular Activities on Student Achievement at the High School Level. The University of Southern Mississippi.

Dalrymple, O., \& Evangelou, D. (2006). The Role of Extracurricular Activities in the Education of Engineers. 9th International Conference on Engineering Education, 24-30.

Denault, A.-S., Ratelle, C. F., Duchesne, S., \& Guay, F. (2018). Extracurricular Activities and Career Indecision: A Look at The Mediating Role of Vocational
Exploration. Journal of Vocational Behavior, 1-39. https://doi.org/https://doi.org/10.1016/j.j vb.2018.11.006

Dhanmeher, B. R. (2014). Impact of Co Curricular Activities on The Non Academic Development of Junior College Students. D. Y. Patil University.

Fitriansyah, R., Fatinah, L., \& Syahril, M. (2020). Critical Review: Professional Development Programs to Face Open Educational Resources in Indonesia. Indonesian Journal on Learning and Advanced Education (IJOLAE), 2(2), 109119.

Green, R. D. (1987). Extracurricular Activities. NASSP Bulletin, 71(497), 151. https://doi.org/10.1177/0192636587071 49729

Guilmette, M., Mulvihill, K., VillemaireKrajden, R., \& Barker, E. T. (2019). Past and Present Participation in Extracurricular Activities is Associated with Adaptive Self-Regulation of Goals, Academic Success, and Emotional Wellbeing Among University Students. Learning and Individual Differences, 73(April), 8-15. https://doi.org/10.1016/j.lindif.2019.04.006

Holloway, J. H. (2006). Connecting Professional Development to Student Learning Gains. Science Educator, 15(1), 37-43. Retrieved from https://eric.ed.gov/?id=EJ773253

Huang, Y. R., \& Chang, S. M. (2004). Academic and Cocurricular Involvement: Their Relationship and The Best Combinations for Student Growth. Journal of College Student Development, 45(4), 391-406.

https://doi.org/10.1353/csd.2004.0049

Jackson, D., \& Bridgstock, R. (2020). What Actually Works to Enhance Graduate Employability? The Relative Value of Curricular, Co-Curricular, and ExtraCurricular Learning and Paid Work. Higher Education. https://doi.org/10.1007/s10734-02000570-x

Ji, H., \& Zhang, L. (2011). Research on 
College Students' Stresses and Coping Strategies. Asian Social Science, 7(10), 30-34.

https://doi.org/10.5539/ass.v7n10p30

King, A. E., McQuarrie, F. A. E., \& Brigham,

S. M. (2020). Exploring the Relationship

Between Student Success and Participation in Extracurricular Activities. SCHOLE: A Journal of Leisure Studies and Recreation Education, 1-17. https://doi.org/10.1080/1937156X.2020. 1760751

Kirsch, C., Aleksić, G., Mortini, S., \& Andersen, K. (2020). Developing Multilingual Practices in Early Childhood Education Through Professional Development in Luxembourg. International Multilingual Research Journal, 1-19. https://doi.org/10.1080/19313152.2020. 1730023

Lawless, H. T., \& Heymann, H. (2010). Sensory Evaluation of Food (Secind; Dennis R. Heldman, Ed.). https://doi.org/10.1007/978-1-44196488-5_16

Lindsey van der Lans. (2012). Wat is de daadwerkelijke meerwaarde van het doen van extracurriculaire activiteiten?

Massoni, E. (2011). Positive Effects of Extra Curricular Activities on Students. ESSAI( The Berkeley Electronic Press), 9(Article 27), 84-87.

Nuijten, M. P. J., Poell, R. F., \& Alfes, K. (2017). Extracurricular activities of Dutch University students and their effect on employment opportunities as perceived by both students and organizations. International Journal of Selection and Assessment, 1-11. https://doi.org/10.1111/ijsa.12190 OR

Oberle, E., Ji, X. R., Guhn, M., SchonertReichl, K. A., \& Gadermann, A. M. (2019). Benefits of Extracurricular Participation in Early Adolescence: Associations with Peer Belonging and Mental Health. Journal of Youth and Adolescence, 48(11), 2255-2270. https://doi.org/10.1007/s10964-01901110-2

Perjuangan, J. (2020). Extracurricular
Management Program to Improve Students 'Non-Academic Achievement Activities in MAN 3 Cirebon. Diadikasia Journal, 1(1), 10-22. https://doi.org/10.21428/8c841009.5494 e $7 \mathrm{~d} 0$

Rees, E. G. (2008). The Effects of Participation in Extracurricular Activities On Academic Performance in Secondary School Students. Regis University.

Saibovich, S. A. (2019). Extracurricular Activities: Success and Development of Communication Skills with the Role of Parents, Public and Home Work. International Journal of Management Science and Business Administration, 6(1), 21-26.

https://doi.org/10.18775/ijmsba.1849-

5664-5419.2014.61.1003

Staff, J., Messersmith, E. E., \& Schulenberg, J. E. (2009). Adolescents and the world of work. In Handbook of adolescent psychology: Contextual influences on adolescent development, Vol. 2, 3rd ed. (pp. 270-313). Hoboken, NJ, US: John Wiley \& Sons Inc.

Stephens, L. J., \& Schaben, L. A. (2002). The Effect of Interscholastic Sports Participation on Academic Achievement of Middle Level School Activities. $\mathrm{Na}$ tional Association of Secondary School Principals Bulletin, 86(630), 34-41. https://doi.org/https://doi.org/10.1177/0 19263650208663005

Tanner, B. (2017). Effects of Extracurricular Activities and Physical Activity on Academic Success. The BYU Undergraduate Journal in Psychology, 12(2), 11. Retrieved from https://scholarsarchive.byu.edu/intuition/vol12/iss2/14

Van Loon, A. W. G., Creemers, H. E., Beumer, W. Y., Okorn, A., Vogelaar, S., Saab, N., ... Asscher, J. J. (2020). Can Schools Reduce Adolescent Psychological Stress? A Multilevel Meta-Analysis of the Effectiveness of School-Based Intervention Programs. Journal of Youth and Adolescence, 49(6), 1127-1145. https://doi.org/10.1007/s10964-02001201-5. 